International Journal of Agriculture, Environment and Bioresearch

Vol. 4, No. 04; 2019

ISSN: $2456-8643$

\title{
OCCURRENCE AND DAMAGE SEVERITY OF CASSAVA PEST AND DISEASES IN TANZANIA
}

\author{
B. S. Wudil, H. Sule, S. G. Haruna and N. B. Sanda \\ Department of Crop Protection Bayero University Kano, PMB 3011 BUK, Kano, Nigeria \\ http://doi.org/10.35410/IJAEB.2019.4413
}

\begin{abstract}
Surveys were conducted during 2015 and 2016 dry seasons in three major cassava producing zones of Tanzania. The studies aimed at establishing the incidence and damage severity of cassava green mite (CGM), cassava mosaic disease (CMD) and cassava brown streak disease (CBSD) on popular cassava varieties. Five districts were chosen in the Lake zone and two districts each from Southern and Eastern zones, to a total of nine districts. Results revealed that M. tanajoa incidence and damage severity were higher in 2015 compared to 2016 and also higher in the Lake zone while Eastern zone recorded the lowest. Younger cassava plants ( $<6$ months) were most attacked by the mites. Cassava varieties, Lufaili, Kachaga, Kufanganya and Naliendele recorded higher damage with the lowest by Var. Ismaili in both years. Moreover, the diseases incidences and severities were higher in 2015 compared to 2016; Southern zone recorded the highest CMD incidence and severity with the least in the Lake zone while higher CBSD incidence and severity were recorded in the Lake zone. More so, altitude and Cassava + cowpea and cassava + cashew inter crops had influenced the incidence and severity of CBSD. Environmental factors especially temperatures played an important role to the distribution of the diseases. Farmers should be sensitized to plant cassava early to escape M. tanajoa attack and there is need for in-depth screening of the popular cassava varieties to come up with resistant cultivars to M. tanajoa, CMD and CBSD as well as their promotion across the country.
\end{abstract}

Keywords: Cassava Brown Streak Disease, Cassava Mosaic Disease, Incidence and M. tanajoa.

\section{INTRODUCTION}

Cassava (Manihot esculenta Crantz: Euphorbiaceae) is considered a food security crop in the East African sub-region. In Tanzania, it is mostly produced in three zones, the Lake Zone, Southern Zone and Eastern Zone (Herzberg et al., 2004; TZNY Cassava, 2012). Cassava production is reported as the food insurance crop in most Sub Saharan African (SSA) countries particularly in the era of climate change when the production of legume and cereal staples is no longer a reliable option (Ferris et al., 1997; Von Braun, 2007). However, the production of this crop in Tanzania is constrained by pests especially cassava green mites, Whiteflies and Cassava mealy bugs and diseases like Cassava mosaic disease, Cassava brown streak disease. Available reports on Africa indicate that, the major cassava pests are: cassava green mite complex, several species of cassava whitefly mainly Bemisia tabaci, and cassava Mealybug, Phenacoccus manihoti (Otim et al., 2006 and Night et al., 2011). While the mealy bug menace was brought 
Vol. 4, No. 04; 2019

ISSN: $2456-8643$

under control in most regions of the continent in 1990s after the release of parasitoid wasps, the diverse whitefly species continued to transmit viral diseases inclusive of cassava brown streak disease (CBSD) and cassava mosaic disease (CMD) (Kariuki et al., 2005), more so,

Mononychellus tanajoa (M. tanajoa) has been a pest of serious concern. Several efforts to control cassava pests and diseases especially M. tanajoa, CMD and CBSD have been geared to the diseases vectors, breeding and the molecular aspects with less emphasis on their spread and distribution especially in the leading cassava producing zones. M. tanajoa was discovered in 1972 at the Ukerewe Islands of the Lake Zone of Tanzania (Msabaha et al., 1988; Nyiira, 1972) while Cassava brown streak disease (CBSD) was first reported in 1936 in Tanzania (Thresh 2003). The disease was observed in several countries of eastern and southern Africa in the 1950s. Following 40 years of waning scientific activity and economic interest in brown streak, CBSD was re-discovered' in Tanzania, Kenya, and Malawi in the 1990s (Rwegasira et al., 2009). The current study aimed at establishing the disease and pest status of the key cassava pest and viral diseases in Tanzania, examine responses of the commonly grown cassava varieties and determine if there exists any environmental influence on their occurrence and distribution considering the different agro-ecological zones of Tanzania.

\section{MATERIALS AND METHODS}

The surveys were conducted in farmers' fields during 2015 and 2016 dry seasons in the three Zones (Lake Zone, Southern Zone and Eastern Zones). Specifically, the surveyed areas were; five districts in the Lake Zone (Sengerema, Misungwi, Kwimba, Bunda and Ukerewe Island), two districts in the Southern Zone (Mtwara rural and Mtwara Municipal), and Eastern Zone (Kibaha and Mkuranga) making a total of nine districts. A total of 5400 plants in 180 fields were assessed during 2015 and 2016 for M. tanajoa, CMD and CBSD incidences and their associated damage severity.

\subsection{M. tanajoa Incidence Assessment}

The incidence was assessed by carefully opening the leaves from the top fully open five leaves using a hand lens (Model No. YT1045/50mm). In each plot, eighteen out of the 36 cassava plants were selected randomly along the diagonals and the presence or absence of the mites was recorded (Evila, et al., 2012).

\subsection{M. tanajoa Leaf damage and Leaf malformation assessment}

The leaf damage and malformation were recorded using a scale of 1 to 5 modified from Nukenine et al., (2002).

- 1 = no obvious symptoms,

- $2=$ less than $5 \%$ leaf chlorosis and the leaf was damaged but no malformation

- $3=$ more than $5 \%$ but less than $50 \%$ leaf chlorosis and mild malformation, 
- 4 = more than 50\% leaf chlorosis with significant reduction in leaf area and severe malformation with significant reduction in shape and

- $5=$ leaf is $100 \%$ distorted or dead and dropped

\subsection{Cassava Mosaic Disease severity and incidence Assessment}

Cassava mosaic disease was monitored by the physical observation on the leaves using a scale of 1 to 5 where 1 indicated no disease and class 5 severe mosaic diseases and leaves severely reduced (Jeremiah and Kulembeka, 2007). Incidence was considered as the percentage of the total number of plants with CMD symptoms.

\subsection{Cassava Brown Streak Disease severity and incidence Assessment}

Field incidence and severity of CBSD were recorded based on shoot and root symptoms. Incidence was considered as the percentage of the total number of plants with CBSD symptoms. A Natural Resources Institute (NRI) scale of 1 (no symptoms) through 5 (severe symptoms) (Hillocks and Thresh, 1998), was used with minor modifications to assess severity(Rwegasira, et al., 2009).

Other data collected were the coordinates (Latitude, Longitude and Altitude) of each surveyed farm using the Geographic positioning System (GPS) (Oregon 450, Germin International Cooperations), the crop age, cassava variety grown, the cropping system (Inter cropped or Sole cropped).

The collected data were subjected to non-parametric (K-Independent samples) analyses in SPSS version 16.0, (SPSS Inc., 2011) and Kruskal-Wallis test was used to establish comparisons among the CGM, CMD and CBSD incidences and the associated damage severities. Multiple regression analysis was carried out to predict the relationship between weather variables and CMD and CBSD incidences and severities.

\section{RESULTS}

The M. tanajoa incidences were significant $(\mathrm{P}<0.05)$ and higher in the Lake Zone followed by the Southern Zone in both years although greater incidence was recorded in 2015 compared to 2016 (Table 1). However, Eastern Zone appeared to have reported the least incidence in the two years. The differences among the Zones as per leaf malformation was only significant $(\mathrm{P}<0.05)$ in 2015, moreover in both years, higher leaf malformation was recorded in the Lake Zone although it was greater in 2015. The least leaf malformation was recorded in the Eastern Zone. 
International Journal of Agriculture, Environment and Bioresearch

Vol. 4, No. 04; 2019

ISSN: $2456-8643$

Table 1. Incidence and Leaf Malformation (mean \pm SD) by M. tanajoa in three different zones of Tanzania during the 2015 and 2016 cropping seasons.

\begin{tabular}{lcc}
\hline Zones & \multicolumn{1}{c}{ INCIDENCE } \\
\hline & $\underline{\text { 2015 Cropping Season }}$ & 2016 Cropping Season \\
Lake Zone & $5.176 \pm 4.8605^{\mathrm{a}}(0.68737)$ & $1.527 \pm 0.686^{\mathrm{a}}(0.097)$ \\
Southern Zone & $1.101 \pm 0.5234^{\mathrm{b}}(0.11716)$ & $1.190 \pm 0.312^{\mathrm{a}}(0.069)$ \\
Eastern Zone & $0.883 \pm 0.7784^{\mathrm{b}}(0.17406)$ & $0.895 \pm 0.293^{\mathrm{b}}(0.066)$ \\
P value & $\mathbf{0 . 0 0 0}$ & $\mathbf{0 . 0 0 0}$ \\
& \multicolumn{2}{c}{ LEAF MALFORMATION } \\
Lake Zone & $1.854 \pm 1.068(0.151)$ & $1.434 \pm 0.365(0.052)$ \\
Southern Zone & $0.315 \pm 0.169(0.038)$ & $1.391 \pm 0.237(0.053)$ \\
Eastern Zone & $0.136 \pm 0.128(0.029)$ & $1.286 \pm 0.280(0.063)$ \\
P value & $\mathbf{0 . 0 0 0}$ & $\mathbf{0 . 1 1 5}$ \\
\hline
\end{tabular}

Cassava age (at $<6$ months) crop significantly $(\mathrm{P}<0.001)$ affected $\mathrm{M}$. tanajoa damage in the three agro-ecological zones in 2016 (Figure 1). Analysis of the crop age influence in each year indicated that cassava plants below six months of age ( $<6$ months) recorded higher damage by M. tanajoa followed by those aged above $<9$ months. The least M. tanajoa damages were recorded on cassava plants of less than 12 months. Moreover, altitude had no significant effects on M. tanajoa damage throughout the three agro-ecological zones although generally higher in 2015 (Figure 1). In the Southern zone (Low altitude, 0 - 99m asl) along the coast high damage was recorded. Similarly, the high altitude $(>500 \mathrm{~m}$ asl) in the Lake zone recorded lower damage score than the Eastern zone.The variation trend was similar but generally minimal in 2016 compared to 2015.

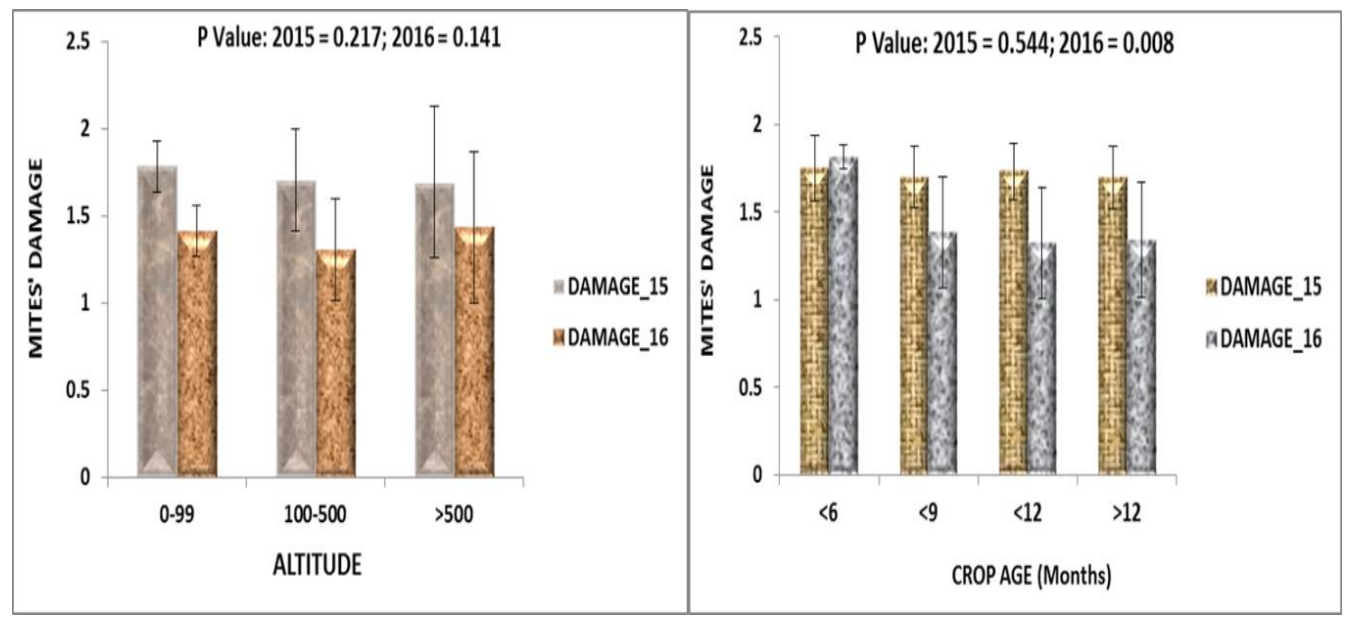

Figure 1: Influence of Altitude and crop age (Months) on M. tanajoa damage in the study areas during 2015 and 2016 dry season 
The M. tanajoa damage on cassava varieties was not significant in both years (Figure 2). However, the cassava varieties assessed had varied M. tanajoa damage with higher damage across the varieties in 2015. In both years, cassava varieties Lufaili, Kachaga, Kufanganya and Naliendele recorded highest damage while others are Kigoma Mafia, Kiroba, Cosmos and Rasta in 2015 (Figure 2). The least damage was recorded Ismaili in 2016.

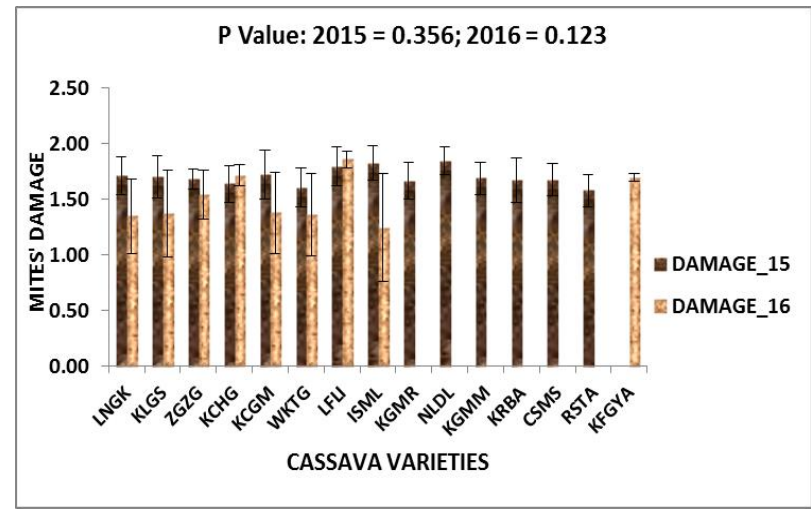

Figure 2: Effects of M. tanajoa damage on some cassava varieties during the 2015 and 2016 dry seasons

Key: LNGK = Liongo Kwimba, KLGS = Kalingisi, ZGZG = Zagazaga, KCHG = Kachaga, KCGM = Kuchangoma, WKTG $=$ Lwakitangaza, LFLI $=$ Lufaili, ISML $=$ Ismaili, KGMR $=$ Kigoma Red, NLDL $=$ Naliendele, KGMM $=$ Kigoma mafia, KRBA = Kiroba, CSMS = Cosmos, RSTA = Rasta, KFGYA = Kufanganya

The effect of intercropping systems on damage caused by M. tanajoa was also assessed and results indicated no significant difference between the sole crop and intercropped plantings in both years (Fig. 3). The comparative assessment of the influence of intercrops with cassava showed that higher M. tanajoa damage was recorded in 2015 compared to 2016. Similarly in 2015, cassava + soybeans mixture recorded the highest damage by M. tanajoa followed by cassava + cowpea mixture. Moreover in 2016, cassava + Sweet potato and cassava + cashew mixture recorded higher damage by M. tanajoa. However, the least damage was recorded by cassava + cashew and cassava + sorghum mixture in 2015 and 2016 respectively. (Fig. 3).

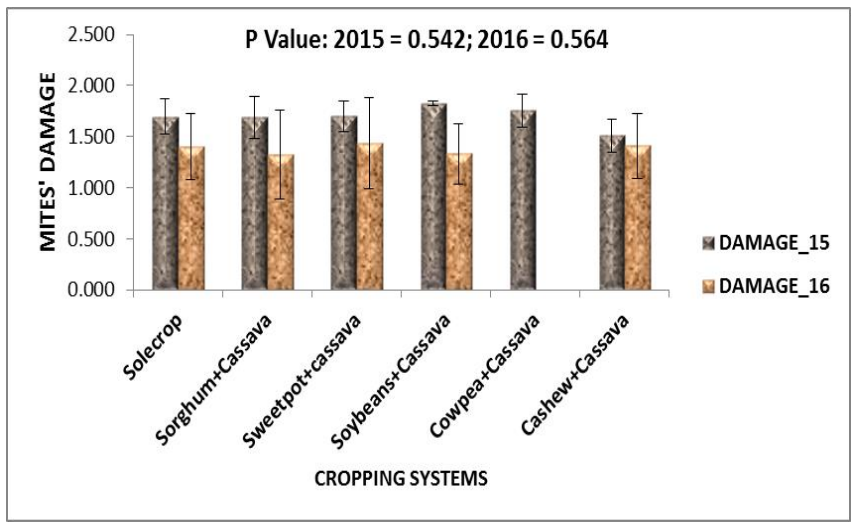


Figure 3: Effects of cropping systems on M. tanajoa damage in three zones of Tanzania during 2015 and 2016 dry seasons

The incidences of cassava mosaic disease were found to be significant $(\mathrm{P}<0.05)$ among the three agro-ecological zones (Table 2). In 2015, Southern Zone recorded the highest CMD incidence followed by the Eastern Zone while the lowest incidence was recorded by the Lake Zone. Similarly, Eastern Zone recorded higher incidence with Lake Zone having the least incidence in 2016. Moreover, the CMD severity was found to record higher in the Southern Zone with the least in the Lake Zone in both years.

Table 2. Incidence and severity of CMD as influenced by agro-ecological zones in Tanzania

\begin{tabular}{|c|c|c|c|c|c|c|}
\hline Zone & $\begin{array}{l}\text { CMD (\%) } \\
\text { Incidence } \\
(2015)\end{array}$ & & $\begin{array}{l}\text { CMD }(\%) \\
\text { Incidence } \\
(2016)\end{array}$ & & $\begin{array}{l}\text { CMD } \\
\text { Severity } \\
(\mathbf{2 0 1 5})\end{array}$ & $\begin{array}{l}\text { CMD } \\
\text { Severity } \\
(2016)\end{array}$ \\
\hline Lake & 15.00 & & 11.668 & & 0.432 & 0.3558 \\
\hline Southern & 22.167 & & 23.3340 & & 0.739 & 0.9715 \\
\hline Eastern & 16.833 & & 14.3330 & & 0.532 & 0.7110 \\
\hline \multicolumn{2}{|c|}{$\mathrm{LSD}(\mathrm{P} \leq 0.05) 0.025^{*}$} & $0.038^{*}$ & & $0.002 * *$ & & \\
\hline
\end{tabular}

P values (significant at $*=0.05, * *=<.001$ )

The incidence and severity of CBSD were highly significant $(\mathrm{P}<0.001)$ across the three different Zones of Tanzania (Table 3). Lake Zone has recorded the highest CBSD incidence (40.27\%) in 2015, while Southern Zone (9.99\%) recorded the lowest incidence. Moreover, highest CBSD incidence was recorded by Lake Zone (37.59\%) in 2016; this is followed by the Eastern Zone. The lowest incidence was recorded by Southern Zone (12.17\%). Similarly, the CBSD severity was found to be higher in the Lake Zone and the lowest was recorded by the Southern Zone in both years.

Table 3. Incidence and severity of CBSD as influenced by agro-ecological zones in Tanzania

\begin{tabular}{|c|c|c|c|c|}
\hline Zone & $\begin{array}{l}\text { CBSD (\%) } \\
\text { Incidence } \\
\text { (2015) }\end{array}$ & $\begin{array}{l}\text { CBSD (\%) } \\
\text { Incidence } \\
\text { (2016) }\end{array}$ & $\begin{array}{l}\text { CBSD } \\
\text { Severity } \\
\text { (2015) }\end{array}$ & $\begin{array}{l}\text { CBSD } \\
\text { Severity } \\
\text { (2016) }\end{array}$ \\
\hline Lake & 40.267 & 37.5996 & 1.392 & 1.443 \\
\hline Southern & 9.999 & 12.1660 & 0.290 & 0.492 \\
\hline Eastern & 24.500 & 19.1670 & 0.774 & 0.923 \\
\hline $\operatorname{LSD}(P \leq 0.05)$ & $0.001 * *$ & $0.009 * *$ & $0.004 * *$ & $0.021^{*}$ \\
\hline
\end{tabular}

$\mathrm{P}$ values (significant at $*=0.05, * *=<.001$ )

The 
responses of the cassava varieties to CMD incidence during the 2015 and 2016 growing seasons were significant $(\mathrm{P}<0.05)$ (Figure 4). In 2015, a local cassava variety, Liongo Kwimba recorded the highest CMD incidence followed by an improved variety, Naliendele. The lowest incidence was recorded by a local variety Ismaili and Kachaga. However in 2016, Kuchangoma (local variety) recorded the least CMD incidence, followed by Kalingisi (local variety), while Zagazaga recorded the highest CMD incidence. Moreover, the in 2015, Lwakitangaza and Ismaili cassava varieties recorded the highest CBSD incidence compared to all other varieties, while Kachaga and Kigoma red were found to be similar and recoded the lowest incidence (Figure 5). In 2016 however, Ismaili and Kalingisi were having the highest CBSD incidence with the lowest recorded by Kuchangoma and Kachaga respectively.

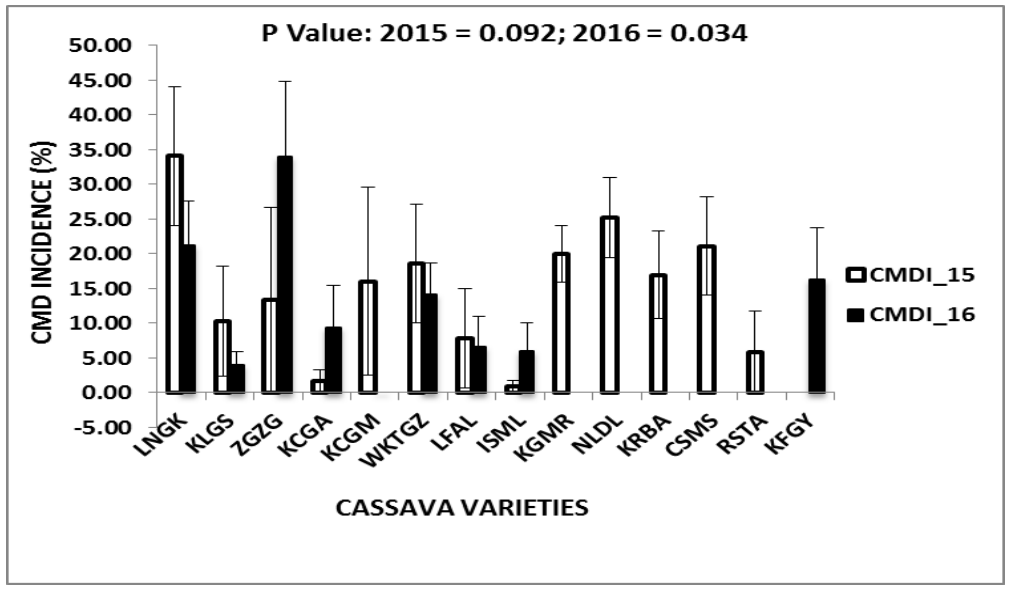

Figure 4. Response of some cassava varieties to CMD incidence during the 2015 and 2016 dry seasons.

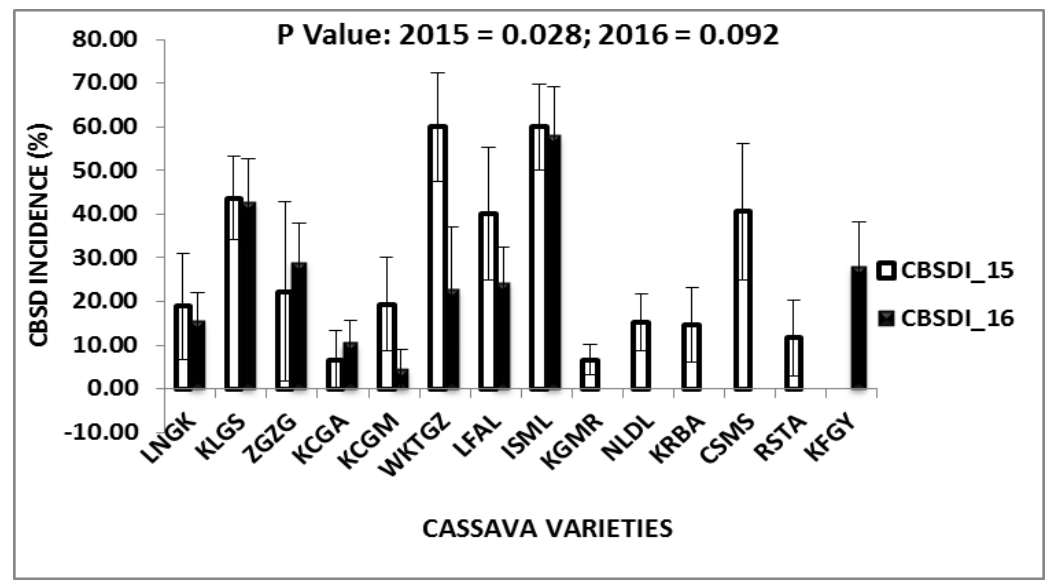

Figure 5: Response of some cassava varieties to CBSD incidence during the 2015 and 2016 dry seasons. 
The CMD and CBSD incidences and damage severity across the two different seasons are shown in table 4. The incidence between 2015 and 2016 dry seasons was not statistically significant. However, the severity was highly significant $(\mathrm{P}<0.001)$ between the two seasons. In 2016, higher (0.67) CMD severity was recorded compared to 2015 (0.52). The influence of seasons on CBSD severity was significant $(\mathrm{P}<0.001)$ and 2016 recorded higher $(1.12)$ severity compared to 2015 (1.01) (Table 4). However, the effect of seasons on CBSD incidence was not significant between the two seasons (2015 and 2016) although, higher (30.04\%) incidence was recorded in the 2015 compared to $2016(27.92 \%)$.

\begin{tabular}{lcl}
$\begin{array}{l}\text { Table 4: Effects of Seasons on Incidence and Severity by CMD } \\
\text { and CBSD during the } 2015 \text { and } 2016 \text { dry Seasons. }\end{array}$ \\
\hline & $\begin{array}{l}\text { CMD (\%) } \\
\text { Incidence }\end{array}$ & $\begin{array}{l}\text { CMD } \\
\text { Severity }\end{array}$ \\
Season & $16.9999 \pm(23.06185)$ & $0.5223 \pm(0.71870)$ \\
\hline $\mathbf{2 0 1 5}$ & $14.5187 \pm(21.67374)$ & $0.6716 \pm(0.77576)$ \\
$\mathbf{2 0 1 6}$ & $\mathbf{0 . 3 0 9}$ & $\mathbf{0 . 0 0 1} * *$ \\
$\mathbf{L S D}(\mathbf{P} \leq \mathbf{0 . 0 5})$ & $\underline{\text { CBSD }(\%)}$ & $\underline{\text { CBSD }}$ \\
& $30.0368 \pm(34.58883)$ & $1.0099 \pm(1.12149)$ \\
$\mathbf{2 0 1 5}$ & $27.8516 \pm(33.00701)$ & $1.1162 \pm(1.12042)$ \\
$\mathbf{2 0 1 6}$ & $\mathbf{0 . 8 1 2}$ & $\mathbf{0 . 0 0 1} * *$
\end{tabular}

Figures in parentheses are (Standard deviation) and $P$ values are significant at $*=0.05, * *=<.001$ )

The disease severities recorded by CMD and CBSD were found to be significantly $(\mathrm{P}<0.001)$ different among the cassava varieties tested in both years (Figure 6). Highest CMD severity was recorded on Liongo Kwimba and Zagazaga in 2015 while the lowest was found on other cassava varieties especially Ismaili, Kachaga and Kalingisi respectively. In 2016, the CMD incidence was found to be higher in cassava varieties Zagazaga and Liongo Kwimba while Kalingisi and Anon recorded the least CMD severity. Moreover, the CBSD shoot severity was found to be significantly $(\mathrm{P}<0.005)$ varied among cassava varieties, with highest severity found on Lwakitangaza, Ismaili, Kalingisi and Zagazaga (Figure 7). However, cassava varieties Kachaga, Kigoma red, Rasta and Naliendele recorded the lowest CBSD shoot severity in 2015. Cassava varieties, Ismaili, Kalingisi, Lwakitangaza and Lufaili recorded the highest CBSD shoot severity while Kachaga, Liongo Kwimba, Kuchangoma were found to have recorded the lowest CBSD shoot severity in 2016. 


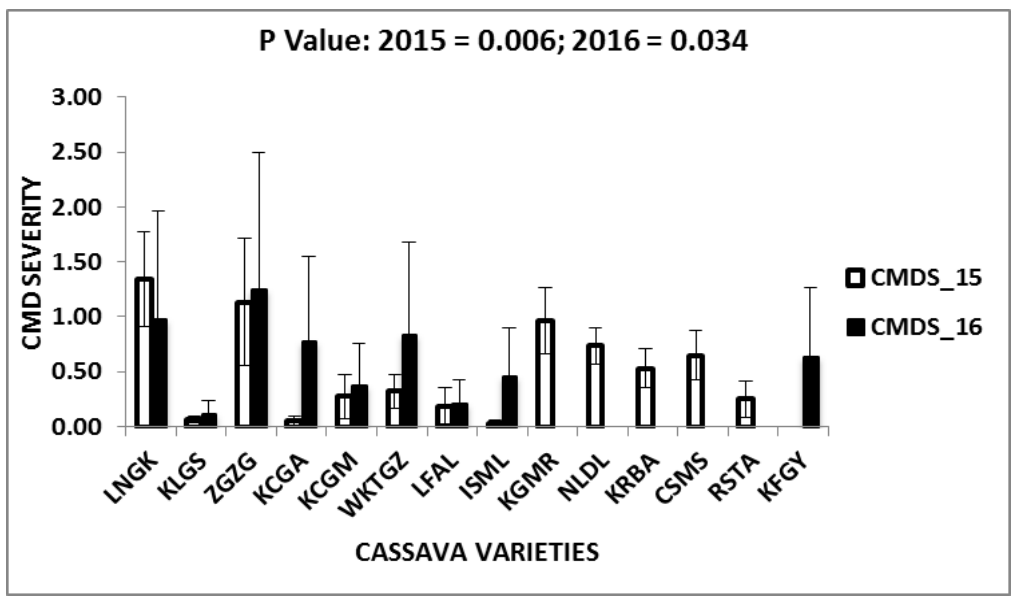

Figure 6: Response of commercial cassava varieties to CMD severity during the 2015 and 2016 dry seasons.

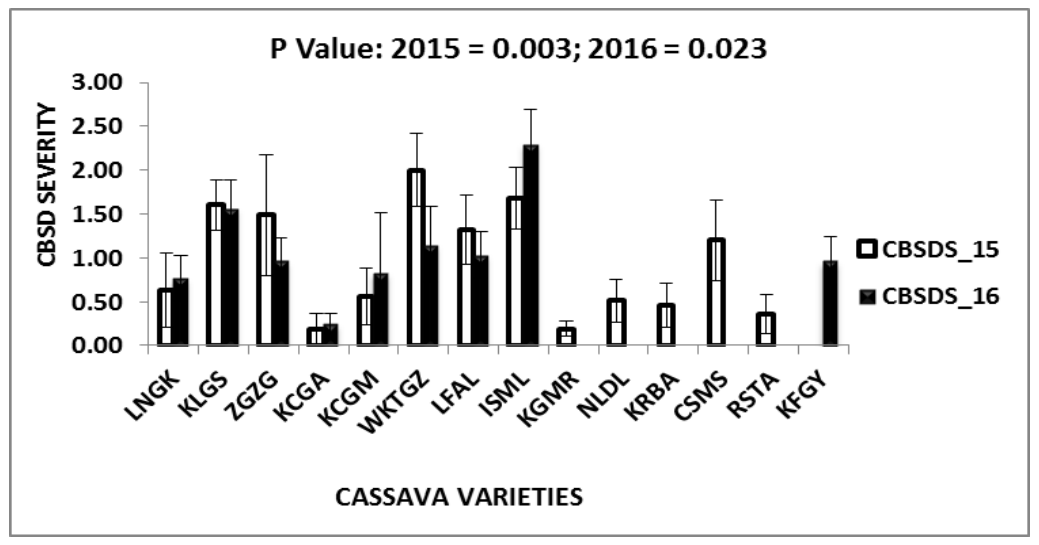

Figure 7: Response of commercial cassava varieties to CBSD severity during the 2015 and 2016 dry seasons.

Altitude had significant impact on CMD $(\mathrm{P}<0.05)$ and CBSD $(\mathrm{P}<0.001)$ severities throughout the three agro-ecological zones (Figure 8$)$. The intermediate altitude $(101-500 \mathrm{~m}$ asl) in the Eastern zone (coastal region) recorded the highest CMD severity. Higher altitude $(>500 \mathrm{~m}$ asl) in the Lake zone significantly $(\mathrm{P}<0.05)$ recorded the lowest $\mathrm{CMD}$ severities in both years while the Low altitude Zone $(5-100 \mathrm{~m}$ asl) along the coast in the Southern zone was found to have recorded the least severity. Higher severity was generally observed in 2016. The CBSD severities across the two cassava growing seasons considering damages inflicted with reference to altitude have significantly $(\mathrm{P}<0.001)$ varied among the three zones. Across all zones and seasons, Lake Zone experienced highest CBSD severities followed by the Eastern Zone. The Southern zone (lower altitudes) recorded least CBSD severities in both years. 


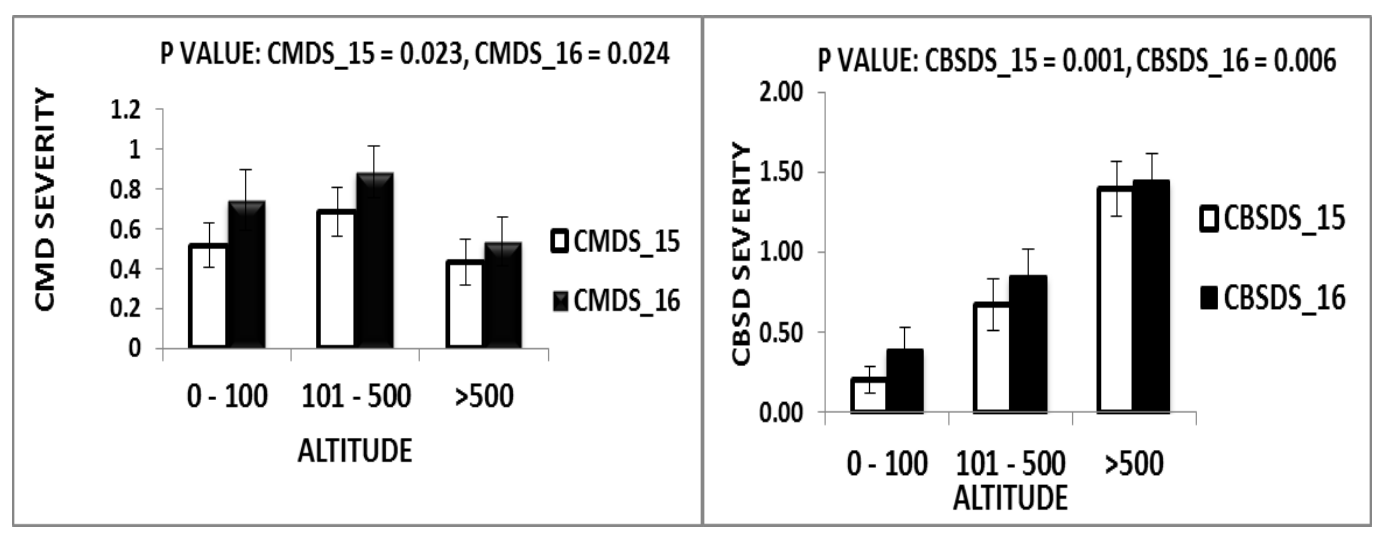

Figure 8.Effects of Altitude on CMD and CBSD shoot severity during the 2015 and 2016 cassava growing seasons in Tanzania

\section{DISCUSSIONS}

Generally, the M. tanajoa incidence and leaf damage were higher in the Lake zone and lowest in the eastern zone in 2015 compared to 2016. This is associated with the variations in weather variables between years and the zones. The Lake and Southern zones have similar pattern and durations of dry season, the most conducive environmental conditions for the survival and perpetuation of M. tanajoa and this explains the reasons for similarities in M. tanajoa incidence, leaf damage and malformation. The dry season normally starts in late May and ends in November in the Lake Zone and April to September or October in the Southern zone. On the other hand, the Eastern zone has a bimodal pattern of rainfall where the dry season starts in July or late June sometimes with showers in between the months. Therefore, the environmental variables especially rainfall, temperature and relative humidity might sometimes differ based on zones, especially Lake and Eastern zone. These factors might have probably dictated for the differences in the survival and perpetuation of the mites among the zones. Several researchers (Onzo et al., 2005; Hanna et al., 2005; Teodoro et al., 2009a,b) have reported a negative correlation between rainfall and mites incidence and subsequent damage. This could be due to the fact that the population build-up of the pest started at the onset of the dry season or closure of the rainy season which is May, while July to August were the peak periods and thus, the damage become higher.

The M. tanajoa damage on cassava varieties was not significant in both years although, they recorded varied M. tanajoa damage with higher damage across the varieties in 2015 . In both years, cassava varieties Lufaili, Kachaga, Kufanganya and Naliendele recorded highest damage while Ismaili had the lowest leaf damage.The differences in response of the cassava varieties to leaf damage and malformation across years were due to their inherent susceptibility/ resistant to M. tanajoa attack. The varietal differences could be attributed to their inherent resistance/tolerance and/or susceptibility to the mites' damage as reported by Toko et al., (1996) that the variation in $\mathrm{M}$. tanajoa damage among the genotypes may be associated with factors inherent in the different genotypes. The damage was observed to fluctuate as reported by 


\section{International Journal of Agriculture, Environment and Bioresearch}

Vol. 4, No. 04; 2019

ISSN: $2456-8643$

Nukenine et al. (2002). The fluctuations in damage by M. tanajoa within and across years could be attributed to differences in weather variables over time and space as well as inherent differences among the tested cassava varieties. The damage led to high loss of the cassava leaves and subsequent reduction in the photosynthetic ability of the cassava and the yield, especially on the susceptible varieties. This has been reported by other researchers that the damage has been equated to the loss of biomass and is an indicative loss of the foliar photosynthetic area (Akinlosotu and Leushner, 1981).

Furthermore, the leaf malformation and damage were found to be higher on crops at 3 and 6 months of age compared to the older ones but this was more pronounced during dry season periods. Ecologically the mite lives and feeds on young leaves and green stems and increases in population density during the transition period between wet and dry seasons (Yaninek, 1994). The responses of the cassava varieties at different ages have been mostly higher on younger plants compared to the older ones ( 9 months) and this has been sometimes fluctuating over time. These indicated that cassava green mites prefer young and tender plants which are succulent and nutritious compared to the fibrous older ones. This is in conformity with reports by other researchers such as Yaninek et al., (1987) and ISC, (2016) that cassava plants aged 2-9 months are the most vulnerable to infestation.

The incidence and severity of CMD as influenced by agro-ecological zones were significantly different. Higher CMD incidences and severity recorded by the Southern zone (coast region) and lowest in the Lake Zone. Moreover, significant differences were found between the two years as per the CMD severity; however, the incidence was not significant. In 2016, the CMD severity was generally higher compared to 2015 which could be attributed to so many factors including variations in the different cassava varieties planted and to a lesser extent the environmental factors in both years. Overall, CMD incidence and severity varied from site to site and between seasons. Similar cases of variability have been reported by several authors in other African countries. In several reports including that of Ariyo et al. (2006) in Nigeria, reported that severity of CMD varied with ecological zones where different cassava varieties were planted. More so, the environmental factors might also be among the possible reasons across seasons. This was also reported by Legg and Thresh (2000) and Legg et al., (2006) the variability of CMD incidence among locations and varieties.

The present study indicated that the CMD incidence and severity were significantly $(\mathrm{P}<0.005)$ different among the cassava varieties in both growing seasons. Cassava varieties such as Liongo Kwimba, Zagazaga and Kufanganya (local varieties) and Naliendele and Cosmos (improved varieties) recorded higher CMD incidences in both years. This could be associated to their inherent susceptibilities to the virus that causes the disease. Moreover, it was recorded that the CBSD incidence and severity were significantly $(\mathrm{P}<0.005)$ different among the cassava varieties in both growing seasons. Cassava varieties such as Lwakitangaza, Ismaili, Zagazaga and Kalingisi (local varieties) have recorded higher CBSD incidences in both years while Kachaga, Kuchangoma, Kigoma red and Rasta cassava varieties recorded the lowest CBSD incidence in 2015; this could be attributed to their inherent susceptibilities and resistant/ tolerant to the virus that causes the disease. It was also observed that most of the cassava varieties that were severely attacked and damage by the CMD were not affected or much affected by CBSD and vice versa, 
similar results were reported by (Rwegasira et al., 2009) that the variations among cassava cultivars in expressing root and foliage symptoms of CBSD has been reported. The inherent characteristics of the susceptibility or resistance of cultivars leads to varied response to CBSV infection (Hillocks et al., 2001).

Moreover, the CBSD incidence and severity were affected by altitude as they increased with an increase in altitude. The Lake Zone recorded the highest incidence in 2015 and 2016) and severity which is followed by the Eastern Zone in 2015 and 2016). The current results have indicated the spread of the disease up to the higher altitudes as it was only reported in the low altitude areas of the country and beyond, this corroborates earlier reports by Hillocks, 1997; Legg and Raya, 1998 and Rwegasira, et al., 2009. Additionally, the presence of CBSD at 1630 masl, with root necrosis more apparent than shoot symptoms has been previously reported. Similarly, symptoms of the disease have since been observed at higher altitudes in Uganda and Tanzania (Alicai et al., 2007; Legg and Raya, 1998) although, limited spread of the disease was recorded. Moreover, the effect of altitude on CBSD could be indirect through temperature variation. The disease was originally common at altitude below $1000 \mathrm{~m}$ asl, at which temperature conditions are considered ideal for the spread of the virus (Rwegasira et al., 2009). In contrast, these findings contradict earlier reports by several researchers that a strong inverse correlation of the incidence of CBSD with altitude is well-documented (Hillocks 2002). More so, there is a report from Mozambique and Tanzania, that the disease prevalence is highest on the Coast ( 0 200 meters above sea level). But recent surveys in 2004 suggested that the neighboring intermediate districts that share boundaries with the coastal districts have rates of infestation (exceeding 40\%) that are not significantly different from the coastal districts of Nampula and Zambezia provinces (Zacarias et al., 2004).

\section{CONCLUSIONS AND RECOMMENDATIONS}

The current findings revealed that M. tanajoa and the two disease are present everywhere cassava is grown in Tanzania. The M. tanajoa incidence and leaf damage severity were higher in 2015 compared to 2016 and were also higher in the Lake zone and lowest in the Eastern zone. The pest prefers younger cassava plants especially under the age of 6 months while cassava Var. Ismaili recorded the lowest leaf damage compared to others in both years. The Southern Zone recorded the highest CMD incidence and severity with the least in the Lake Zone while the later proved to have higher CBSD than the former. Similarly, the diseases incidence and severity were higher in 2015 compared to 2016. Environmental factors especially temperatures played an important role to the distribution of the diseases. Farmers should be sensitized to plant cassava early to escape the M. tanajoa attack while planting of cassava var. Ismaili should be encouraged. There is need for in-depth screening of most of the cassava varieties (especially local varieties) in order come up with the resistant cultivars to M. tanajoa, CMD and CBSD as well as their promotion across the country.

\section{Acknowledgements}

The Tertiary Education Trust Fund (TetFund) of the Federal Republic of Nigeria is acknowledged for funding the study. The Bayero University Kano, Nigeria (employer) for the 
nomination and opportunity given to me to undergo the training. More so, the Lake Zone Agricultural Research and Development Institute (LZARDI), the Sugarcane Research Institute (SRI), Kibaha for the staff and material assistance as well as the gestures from Dr. B. Kazuzuru of the Sokoine University Laboratory for Interdisciplinary Statistical Analysis (SUALISA), Prof. M. Mwatawala (Head of Department), Mrs. Catherine S. of the Department of crop Science and Horticulture, Sokoine University of Agriculture, Morogoro, Tanzania.

\section{REFERENCES}

[1] Akinlosotu, T.A. and Leuschner, K. Outbreaks of two new pests (Mononychellus tanajoa and Phenacoccus manihoti) in southern Nigeria. Tropical Pest Management, pp. 27: 247-250, 1981.

[2] Alicai, T., Omongo, C. A., Maruthi, M. N., Hillocks, R. J., Baguma, Y., Kawuki, R., Bua, A., Otim-Nape, G. W.and Colvin, J. Re-emergence of cassava brown streak disease in Uganda.Plant Disease, pp. 91: $24-29,2007$.

[3] Ariyo,O. A.,Dixon, A. G. O. and Atiri, G. I. Whitefly Bemisiatabac i(Homoptera: Aleyrodidae) Infestation on Cassava Genotypes Grown at Different Ecozones in Nigeria," Journal of Economic Entomolgy. Pp. 98(2): $\quad$ 611-617, 2006.

[4] Évila, C. Costa, Adenir V. Teodoro, Adriano S. Rêgo, Anilde G.S. Maciel and RenatoSarmento Population structure and dynamics of the cassava green mite Mononychellus tanajoa (Bondar) and the predator Euseius ho (DeLeon) (Acari: Tetranychidae, Phytoseiidae). Arthropods. Pp. 1(2): 55 - 62, 2012.

[5] Ferris, R. S., Whyte, B., Khizzah, A., Legg J. Opportunities in commercializing cassava in East and Southern Africa.African Crop Science, pp. 6:1427-1433, 1997.

[6] Gutierrez, J. The cassava green mite in Africa: one or two species (Acari:Tetranychidae). Experimental and Applied Acarology, pp. 3:163-168, 1987.

[7] Hanna, R., Onzo, A. and Lingeman, R. Seasonal cycles and persistence of an acarine predator-prey system on cassava in Africa.Population Ecology, pp. 47:107-117, 2005.

[8] Herren H. R. and Bennett F. D. Cassava pests, their spread and control. In: Hawksworth D. L. (ed). Advancing Agricultural Production in Africa. In Proceedings of CAB's First Scientific Conference, Arusha, Tanzania.Farnham Royal UK. Commonwealth Agricultural Bureau (CAB) Slough, pp. 110-114, 1984.

[9] Herzburg, F. N.,MahunguM.,Mignouna J.and A. Kullay. Assessement of genetic Diversity of Local Varieties of Cassava in Tanzania usingMolecular Markers. African Crop Science Journal, pp. 12 (3): 171 - 187, 2004.

[10] Hillocks, R. J. Cassava virus diseases and their control with special reference to southern Tanzania. Integrated Pest Management Reviews. Pp. 2:125-138, 1997. 
Vol. 4, No. 04; 2019

ISSN: $2456-8643$

[11] Hillocks, R. J. and Thresh, J. M. Cassava mosaic and cassava brown streak virus diseases inAfrica: a comparative guide to symptoms and aetiologies. Natural Resources Institute,UK. 10, pp. 1998.

[12] Hillocks, R. J., Raya, M. D., Mtunda, K. and Kiozia, H. .Effects of brown streak virus disease on yield and quality of cassava in Tanzania. Journal of Phytopathology, pp. 149: 389 394, 2001.

[13] Hillocks, R. J. Cassava in Africa. In: Hillocks R. J., Thresh JM., and Bellotti A. C., (Eds).Cassava Biology, Production and utilization. CAB International. Pp 41-54, 2002.

[14] ISC, (Invasive Species Compendium) (2016). [www.cabi.org/isc/datasheet] site visited on31/05/2016.

[15] Jeremiah, S.C. and Kulembeka, H.P. Screening of local cassava varieties against cassava mosaic disease and cassava green mite. Proceedings of the 13th ISTRC Symposium, pp. 341 344, 2007.

[16] Kariuki, C.W., Hanna R, Toko M. The impact of a predatory mite, Typhlodromalus aripo De Leon (Acari: Phytoseiidae) on cassava green mite population and yield of cassava in the field. African Crop Science Proceeding.pp. 7:1401-1405, 2005.

[17] Legg, J.P. and Raya, M. D. Survey of Cassava Virus Diseases in Tanzania. International Journal of Pest Management. Pp. 44: 17 - 23, 1998.

[18] Legg, J. P. and Thresh, J. M. "Cassava Mosaic Virus Dis- ease in East Africa: A Dynamic Disease in a Changing Environment," Advances in Virus Research, 71(1-2), pp. 135-149, 2000. .doi:10.1016/S0168-1702(00)00194-5

[19] Legg, J. P. Owor, B. Sseruwagi, P. and Ndunguru, J. Cassava Mosaic Virus Disease in East and Central Africa: Epidemiology and Management of Regional Pandemic," Advances in Virus Research, 67: pp. 355-418, 2006. doi:10.1016/S0065-3527(06)67010-3

[20] Megevand, B.,Yaninek J.S, Friese D.D. Classical biological control of cassava green mite. Symposium XI of the International Conference of Tropical Entomology. Africa- Wide Biological Program of Cassava Pests.Insect Sci Application, pp. 18:871-874, 1987.

[21] Msabaha, M. A. M., Ndibaz, R.E. and Nyango, A.K. Cassava Research Advances in Tanzania for the Period 1930 - 1988.Tanzania Agricultural Research Organisation, Ministry of Agriculture and Livestock Development, Tanzania. 25 pp. 1988.

[22] Night, G. P.,Asiimwe, G.,Gashaka, D.,Nkezabahizi, J. P., Legg, G.,Okao-Okuja, R.,Obonyo, C.,Nyirahorana, C.,Mukakanyana, F.,Mukase, I.,Munyabarenzi, M. Mutumwinka. Occurrence and distribution of cassava pests and diseases in Rwanda.Agric. Ecosyst. Environ. Pp. 2011. 
[23] Nukenine, E.N., Hassan, A.T., Dixon, A.G.O. and Fokunang, C.N. Population Dynamics of Cassava Green Mite, Mononychellus tanajoa (Bondar) (Acarina: Tetranichidae) as influenced by Varietal Resistance. Pakistan Journal of Biological Sciences, pp. 5(2): 177 - 183, 2002.

[24] Nyiira, Z. M. Report of Investigation of Cassava mite, Mononychellus tanajoa (Bondar).Kawanda research Station, Kampala, Uganda, Unpublished report, 14 pp. 1972.

[25] Onzo, A., Hanna, R. and Sabelis, M. W. Temporal and spatial dynamics of an exotic predatory mite and its herbivorous mite prey on cassava in Benin, West Africa. Environmental Entomology, pp. 34: 866 - 874, 2005.

[26] Otim, M. Legg ,J., Kyamanywa,S.,Polaszek,A.,Gerling, D. Population dynamics of Bemisiatabaci (Homoptera:Aleyrodidae)parasitoidsoncassavamosaicdisease-resistant and .BiocontrolSci.Technol.16, pp. 205-214, 2006..

[27] Report on TZNY Cassava. Cassava: Adding Value for Africa. Driving demand for Cassava in Tanzania: Draft Report. pp. 61, 2012.

[28] Rwegasira, G. M., Rey M.E.C., Caroline, C. M. and Legg, J. P. Cassava Brown Streak Virus Sequences for 43 Isolates from Tanzania. 2009, http://www.ncbi.nlm.nih.gov/ site accessed December, 24th 2016.

[29] Statistical Package for Social Sciences. .SPSS version 16.0 SPSS Inc, 2011.

[30] Thresh J. M., Brief History of Cassava Brown Streak Virus Disease. Pp5 -6.In: Legg, J.P. and Hillocks, R.J. (Eds), 2003. Cassava Brown Streak Virus Disease: Past, Present and Future. In Proceedings of an international workshop, Mombasa, Kenya, Natural Resources International Limited, Aylesford, UK. pp. 27-30, 2003.

[31] Teodoro, A. V., Klein, A. M. and Tscharntke, T. Temporally mediated responses of the diversity of coffee mites to agro forestry management.Journal of Applied Entomology, pp. 133: $659-665,2009$ a.

[32] Teodoro, A., Klein, A. M. and Reis, P. R. Agro forestry management affects coffee pests contingent on season and developmental stage. Agricultural and Forest Entomology, pp. 11: 295 $-300,2009 b$.

[33] Toko, M., Yaninek, J. S. and O'Neil, R. J. Response of Mononychellus tanajoa (Acari: Tetranychidae) to Cropping Systems, Cultivars and Pest Interventions. Environmental Entomology, pp. 25 (2): 237 - 249, 1996.

[34] Von Braun J. The World Food Situation: New Driving Forces and Required Actions. IFPRI's Biannual Overview of the World Food situation presented to the CGIAR. Animal General Meeting, Beijing, Von Braun. Pp. 334-336, 2007.

[35] Yaninek J.S., Herren H.R. and Gutierrez H.P. The biological basis for the seasonal outbreaks of cassava green mites in Africa. Insect Science and its Application, pp. 8:8 61-865, 1987. 
International Journal of Agriculture, Environment and Bioresearch

Vol. 4, No. 04; 2019

ISSN: $2456-8643$

[36] Yaninek, J. S. Cassava Green Mite Intervention Technologies. African Crop Science Journal, pp. 4: $361-367,1994$.

[37] Zacarias, A.M., Botha, A.M., Labuschagne, M.T., Benesi, I.R.M. Characterization and genetic distance analysis of cassava (ManihotesculentaCrantz) germplasm from Mozambique using RAPD fingerprinting. Euphytica. pp. 138: 49-53, 2004. 